\title{
Should Juvenile Offenders Ever Be Sentenced to Life without the Possibility of Parole?
}

\author{
Laurence Steinberg $^{\mathrm{a}} \quad$ Elizabeth Scott ${ }^{\mathrm{b}}$

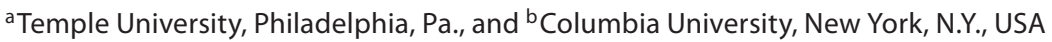

The United States is one of the only industrialized nations that sentences individuals to life in prison without the possibility of parole for crimes committed as juveniles. Last November, the United States Supreme Court heard oral arguments in two cases that asked whether this practice is constitutional. Those who hope the Court will ban this sentence have pointed to its 2005 decision in Roper v. Simmons abolishing the juvenile death penalty, and argued that the logic applied in that opinion to exclude minors from capital punishment should exempt them from life without parole as well. In the current cases, as in Roper, scientists pointed to recent research on adolescent brain and behavioral development to argue that juveniles are fundamentally different from adults in ways that warrant their differential treatment under the law [Steinberg, 2009].

The sentence of life in prison without parole is a judgment that an offender will never be fit to rejoin civil society. This harsh punishment may be suitable for some adults who have committed terrible crimes, but it is never a fair sentence for a juvenile, whose character is unformed and whose involvement in crime reflects the immature judgment of adolescence. In deciding to end the juvenile death penalty, the Supreme Court repeatedly emphasized the relative immaturity of minors, even at age 17 - a point that is well established in behavioral research and finds growing support in brain science. Writing for the majority, Justice Kennedy observed that juveniles' impulsivity, recklessness, and susceptibility to peer pressure made them inherently less responsible than adults. Kennedy also noted juveniles' potential for rehabilitation, because their personality and character traits are transitory and less fixed than adults'.

The Court's deliberations in the recent cases did not focus on whether adolescents are less mature than adults, something that has become so widely accepted since Roper that it is now unquestioned. Rather, the issue that garnered the Court's attention in the life without parole cases is whether immaturity should be used to distinguish adolescents as an entire class (thereby prohibiting life without parole for all individuals younger than 18), or whether it should be taken into account on a case-by-case basis (thereby allowing courts to treat psychologically mature adolescents as adults).

\begin{tabular}{ll}
\hline KARGER & ○ 2010 S. Karger AG, Basel \\
Fax +41 61 306 12 34 & 0018-716X/10/0532-0053\$26.00/0 \\
$\begin{array}{l}\text { E-Mail karger@karger.ch } \\
\text { www.karger.com }\end{array}$ & $\begin{array}{l}\text { Accessible online at: } \\
\text { www.karger.com/hde }\end{array}$
\end{tabular}

Laurence Steinberg

Department of Psychology, Temple University

Weiss Hall, 1701 North 13th Street

Philadelphia, PA 19122-6085 (USA)

E-Maillds@temple.edu 
Reasonable arguments for each of these positions can be made based on developmental science. On the one hand, there is considerable variability among sameaged individuals in their psychological maturity, and surely some older adolescents have the psychological maturity of adults. On the other hand, psychologists are notoriously bad at predicting adult functioning from snapshots taken when individuals are still teenagers. We are moderately good at doing so in the aggregate (and even still, we are thrilled when adolescent predictors explain a mere $25 \%$ of the variance in adult outcomes), but we are terrible when it comes to making predictions about individuals. In the final analysis, it seems prudent to reserve making irrevocable decisions about individuals whose development is still a work in progress when it is possible to defer doing so until they have reached adulthood [Scott \& Steinberg, 2008].

There is no question that teenagers who commit serious crimes should be held accountable and punished, and that society must be protected from young people who are violent and dangerous. But studies show that the vast majority of juveniles who commit crimes - even very serious crimes - grow up to be law-abiding adults, and that it is impossible to reliably predict which juvenile offenders will become career criminals. Absent our ability to do this, and in light of what developmental science tells us about the capacity for adolescents to change, it makes no sense to lock up any young offender and throw away the key.

\section{References}

Scott, E., \& Steinberg, L. (2008). Rethinking juvenile justice. Cambridge: Harvard University Press.

Steinberg, L. (2009). Adolescent development and juvenile justice. Annual Review of Clinical Psychology, $5,47-73$. 